Tropical Journal of Pharmaceutical Research September 2019; 18 (9): 1955-1960

ISSN: 1596-5996 (print); 1596-9827 (electronic)

(1) Pharmacotherapy Group, Faculty of Pharmacy, University of Benin, Benin City, 300001 Nigeria.

\title{
GC-MS metabolic profiling and anti-urease activity of non- polar fractions of Calligonum Polygonoides L. (Polygonaceae) and Crateva Adansonii DC. Prodr. (Capparaceae)
}

\author{
Irfan Pervaiz*, Saeed Ahmad, Adeel Arshad, Umair Khurshid, Abdul Basit \\ Faculty of Pharmacy \& Alternative Medicine, Islamia University, Bahawalpur, Pakistan
}

*For correspondence: Email: irfanpharmacist@gmail.com; Tel: +92-334-9808970

Sent for review: 4 May 2019

Revised accepted: 22 August 2019

\begin{abstract}
Purpose: To determine the urease-inhibitory activity and chemical constituents of fractions of Calligonum polygonoides and Crateva adansonii separated by physical properties.

Methods: The anti-urease activities of different fractions of the plants (methanol, $n$-hexane, $\mathrm{CHCl}_{3}, \mathrm{n}$ butanol) were evaluated using a standard procedure. The chemical constituents of the extracts with the highest urease-inhibitory activity were determined by gas chromatography-mass spectrometry.

Results: The $n$-hexane fractions of both plants had higher urease-inhibitory activity and a lower halfmaximal inhibitory concentration $\left(I C_{50}\right)$ than the other extracts. GC-MS evaluation revealed that $n$ hexane fraction of $\boldsymbol{C}$. polygonoides was rich in fatty acids (39.36\%), sterols (22.29\%), long chain alkanes $(98.5 \%)$, and a few volatiles $(5.26 \%)$, while the $n$-hexane fraction of C. adansonii had high levels of alkanes (35.03\%), sterols (10.46\%), fatty acid esters (46.82 \%), and triterpenes (23.76\%). Conclusion: The $n$-hexane fractions of the plants demonstrate high urease-inhibitory activity. Thus, these plant-based anti-urease fractions can potentially serve as a starting point for the development of novel antibacterial agents with enhanced efficacy and reduced antibiotic resistance in the treatment of pathological conditions and infections associated with urease.
\end{abstract}

Keywords: Calligonum polygonoides, Crateva adansonii, Urease, Natural products, Antibiotics, Helicobacter pylori

This is an Open Access article that uses a fund-ing model which does not charge readers or their institutions for access and distributed under the terms of the Creative Commons Attribution License (http://creativecommons.org/licenses/by/4.0) and the Budapest Open Access Initiative (http://www.budapestopenaccessinitiative.org/read), which permit unrestricted use, distribution, and reproduction in any medium, provided the original work is properly credited.

Tropical Journal of Pharmaceutical Research is indexed by Science Citation Index (SciSearch), Scopus, International Pharmaceutical Abstract, Chemical Abstracts, Embase, Index Copernicus, EBSCO, African Index Medicus, JournalSeek, Journal Citation Reports/Science Edition, Directory of Open Access Journals (DOAJ), African Journal Online, Bioline International, Open-J-Gate and Pharmacy Abstracts

\section{INTRODUCTION}

Many traditional medicines were derived from natural sources and contain a wide variety of biologically active compounds [1,2] with diverse pharmacological activities [3]. Along with their derivatives, these naturally derived compounds constitute more than half of the drugs that have been approved by the U.S. Food and Drug Administration. It is believed that natural sources still hold a rich collection of products with pharmacological potential, that is, undiscovered drugs [4]. In this study, we have assessed two desert plant species for their potential to serve as natural sources of biological compounds capable of inhibiting urease activity. The latter has been 
implicated in a variety of diseases and pathological conditions.

Urease (urea amidohydrolase: EC 3.5.1.5) catalyzes the hydrolysis of urea to yield ammonia and carbon dioxide [5-8], and has been implicated in the pathology of several urinary diseases, including pyelonephritis, urolithiasis, and the formation of infection-induced urinary stones $[9,10]$. Urease is a major factor in gastritis and peptic ulcers that result from Helicobacter pylori infections, which also cause chronic inflammation that increases the risk for gastric cancer [11,12]. Thus, urease inhibitors may be an effective treatment of these conditions. Many of the urease inhibitors prescribed at present, for example, phosphorodiamidates, hydroxamic acid derivatives, and imidazoles, are not ideal clinical choices, due to either high toxicity or instability [13]. Therefore, there is great interest in the identification of novel urease inhibitors, and natural sources hold promise. Particularly, medical researchers hope to identify compounds with low toxicity, few side effects, high bioavailability, and great stability $[14,15]$.

Two different plant species were studied as a possible potential source of natural urease inhibitors. Calligonum polygonoides Linn. (common names are Phog or Phogra) is a leafless slow-growing woody shrub that has smooth stems with branches mostly found in the Cholistan region of Pakistan. Its juice is used in the eye as an antidote for scorpion sting; the latex is used to treat eczema, dog bites, and to induce abortion. Decoction of the roots is used, in combination with catechu, as a gargle to relieve sore gums [16]. Crateva adansonii DC, of the family Capparidaceae is commonly called "Barna" or "Burma" in the Indian Subcontinent and "garlic pear" in English [17,18]. Its powdered bark is used in the treatment of urinary, renal tubules, gastro-intestinal, and uterine infection [18]. In ethno-medicine, the plant is used in conditions associated with inflammation, specifically asthma, snakebites, and as an astringent. Its roots are used in the treatment of syphilis, jaundice, and yellow fever [19]. This plant is known for its antimicrobial and antitrypanosomal activities [20,21].

\section{EXPERIMENTAL}

\section{Collection and drying of plant materials}

The entire aboveground portions of $C$. adansonii and $C$. polygonoides were collected near Hasilpur Road in the Cholistan desert region of Pakistan during March and April of 2016. The identity of the plants was authenticated by Prof
Ghulam Sarwer of the Botany Department of Islamia University, Bahawalpur. Voucher specimens were deposited in the Herbarium of the Department of Life Sciences, Islamia University, Bahawalpur with the voucher numbers: 471/LS for C. polygonoides and 472/LS for $C$. adansonii. Plant materials were air dried, pulverized to a coarse powder, and hermetically sealed in polyethylene bags until extraction [22,23].

\section{Extraction and fractionation}

Pulverized samples of $C$. adansonii $(700 \mathrm{~g})$ and C. polygonoides $(900 \mathrm{~g})$ were thoroughly extracted, separately, with $15 \mathrm{~L}$ methanol, and the extracts were filtered through Whatman No.1 filter paper and concentrated under reduced pressure to yield $144 \mathrm{~g}$ of a highly viscous residue. The residue was suspended in $500 \mathrm{~mL}$ of distilled water and sequentially fractionated with n-hexane $(6 \times 1000 \mathrm{~mL}), \mathrm{CHCl}_{3}(6 \times 1000$ $\mathrm{mL})$, and n-butanol ( $6 \times 1000 \mathrm{~mL})$ to furnish the following fractions: $C$. polygonoides [n-hexane (19 g), $\mathrm{CHCl}_{3}$ (125 g), n-butanol (400 g)], and $C$. adansonii [n-hexane (25 g), $\mathrm{CHCl}_{3}(79 \mathrm{~g})$, nbutanol $(175.5 \mathrm{~g})]$.

\section{Urease inhibition assay}

The reaction mixture $(300 \mu \mathrm{L})$ was prepared by mixing $100 \mu \mathrm{L}$ Jack bean urease $200 \mu \mathrm{L}$ assay buffer (100 mM KH${ }_{2} \mathrm{PO}_{4}, \mathrm{pH} 6.8$ ), $0.0007 \mu \mathrm{g} / \mu \mathrm{L}$ urea, and $100 \mu \mathrm{L}$ of plant fraction in a 96-well plate and incubating for $30 \mathrm{~min}$ at $37^{\circ} \mathrm{C}$. The ammonia released was quantified with the phenol-hypochlorite method [24] as follows: 500 $\mu \mathrm{L}$ of solution I (containing $5.0 \mathrm{~g}$ phenol and 25 $\mathrm{mg}$ of sodium nitroprusside) and $500 \mu \mathrm{L}$ of solution II (containing $2.5 \mathrm{~g}$ sodium hydroxide and $4.2 \mathrm{~mL}$ of sodium hypochlorite in $500 \mathrm{~mL}$ of distilled water) were added to the wells at $37^{\circ} \mathrm{C}$ for $30 \mathrm{~min}$, after which the absorbance due to production of blue coloured indophenol was measured at $625 \mathrm{~nm}$ against the control. Thiourea $(0.5 \mathrm{mmol})$ was used as standard inhibitor. All assays were performed in triplicate in a final volume of $1 \mathrm{~mL}$. Urease-inhibitory activity was expressed as in Eq 1 .

$H(\%)=\{(A c-A s) / A c\}$

where Ac and As are the absorbance of control and test samples, respectively.

\section{Gas chromatography-mass spectrometry (GC-MS) profiling}

Sample volumes of $1 \mu \mathrm{L}$ were injected into the GC-MS in the splitless mode using a hot-needle 
technique. The GC-MS system consisted of an Agilent 7693A ALS (Automatic Liquid Sampler), a GC 7890A gas chromatograph, and an Agilent 5975C quadrupole mass spectrometer (Agilent, Santa Clara, CA 95051, USA). Gas chromatography was performed on a $30-\mathrm{m}$ capillary column HP-5 MS of $0.25 \mathrm{~mm}$ internal diameter with an integrated guard column and a $0.25 \mu \mathrm{m}$ film (Agilent, Santa Clara, CA 95051, USA). The injection temperature was $230^{\circ} \mathrm{C}$, the interface was set to $250{ }^{\circ} \mathrm{C}$, and the ion source was adjusted to $200{ }^{\circ} \mathrm{C}$. The carrier gas was helium at a constant flow rate of $1 \mathrm{~mL} / \mathrm{min}$. The temperature program was $2 \mathrm{~min}$ isothermal heating at $60^{\circ} \mathrm{C}$, followed by a $5^{\circ} \mathrm{C} / \mathrm{min}$ oven temperature ramp to $80{ }^{\circ} \mathrm{C}$ and a final 5-min heating at $10-310{ }^{\circ} \mathrm{C}$. The system was then temperature equilibrated for $6 \mathrm{~min}$ at $70^{\circ} \mathrm{C}$ prior to injection of the next sample. Mass spectra were recorded at two scans/s with an $\mathrm{m} / \mathrm{z}$ of $50-$ 650 scanning range. The chromatograms and mass spectra were evaluated using the Agilent MSD ChemStation software. Processed data were checked manually and corrected when necessary before subjecting to further data analysis. Metabolite peaks were quantified by calculating the percentage of peak area after comparing with the sum of peaks of other compounds. Metabolites were identified by comparison of retention times recorded with different mass spectrum data libraries (NIST, Wiley Registry).

\section{Statistical analysis}

Data are expressed as mean \pm SEM of at least three independent experiments. Statistical analysis of data was performed using one-way analysis of variance (ANOVA) followed by Fischer's least significant difference (LSD) posthoc test. Level of significance was set at $p \leq$ 0.05 . SPSS version 20.0 was used for all statistical calculations.

\section{RESULTS}

\section{Urease inhibition}

Table 1 shows the percentage inhibition of urease and the half maximal inhibitory concentration $\left(\mathrm{IC}_{50}\right)$ values of different fractions of C. polygonoides and C. adansonii. The nhexane fraction of both plant species had the greatest inhibition of urease: this extract of $C$. polygonoides inhibited urease activity $93.25 \%$ and had an $\mathrm{IC}_{50}$ value of $12 \pm 0.68 \mu \mathrm{g} / \mathrm{mL}$ These values for $C$. adansonii were $95 \%$ and $10 \pm 0.55$ $\mu \mathrm{g} / \mathrm{mL}$, respectively. These values for these two extracts were not significantly different $(p=0.55$ for percentage inhibition and $p=0.56$ for $\left.\mathrm{IC}_{50}\right)$, but the values for the percentage inhibition and $I_{50}$ values of the other fractions were significantly different $(p \leq 0.05)$.

Table 1: Urease inhibition by different fractions of $C$. polygonoides and $C$. adansonii extracts and thiourea as a positive control

\begin{tabular}{|c|c|c|}
\hline Sample & $\begin{array}{c}\text { Urease } \\
(5 \mathrm{mg} / \mathrm{ml}) \\
\text { Inhibition (\%) }\end{array}$ & $\begin{array}{c}\mathrm{IC}_{50} \\
(\mu \mathrm{g} / \mathrm{ml})\end{array}$ \\
\hline Thiourea (0.5 mmol) & 98 & $1.2 \pm 0.08$ \\
\hline Methanol-CP & 58.5 & $20 \pm 0.64$ \\
\hline n. Butanol-CP & 63.8 & $30 \pm 0.23$ \\
\hline Chloroform-CP & 45.8 & $25 \pm 0.45$ \\
\hline n. Hexane-CP & 93.25 & $12 \pm 0.67$ \\
\hline Methanol-CA & 39.1 & - \\
\hline n. Butanol-CA & 41.26 & - \\
\hline Chloroform-CA & 32.6 & - \\
\hline n. Hexane-CA & 95 & $10 \pm 0.55$ \\
\hline
\end{tabular}

Samples are described by their extraction solventplant source (CP, C. polygonoides; CA, C. adansonii); percentage inhibition values are expressed as mean \pm SEM; $n=3$

\section{GC-MS of n-hexane fraction of $C$. polygonoides}

Thirty-five compounds were identified in the GCMS spectrum of the n-hexane fraction of $C$. polygonoides (Table 2). Seven volatile compounds were discovered. We detected 2hexenal $(0.3 \%)$, which is known to inhibit urease [25]. The n-hexane fraction of $C$. polygonoides contained fatty acids in the range of 9-26 C atoms. Six alkanes were found: nonacosane (3.7 $\%)$, dotriacontane $(20.65 \%)$, tritriacontane (4.55 $\%)$, tetratriacontane $(12.66 \% \mathrm{~min})$, untriacontane $(50.16 \%)$, and pentatriacontane $(2.53 \%)$. Six sterols were identified. These were: cycloartenol (7.5\%), campesterol (1.8\%), stigmasterol (6.99 $\%)$, $\beta$-sitosterol $(12.8 \%)$, sitostenone (5.3\%), and $\beta$-amyrin $(9.7 \%)$.

\section{GC-MS of n-hexane fraction of $C$. adansonii}

Table 3 shows phytocompounds in the n-hexane (non-polar) fraction of $C$. adansonii from GC-MS. Fatty acid esters with 17-20 C atoms were detected, and the methyl ester of hexadecanoic acid was present at the greatest percentage (13.589\%). Five alkanes were identified, but more notably six medicinally important triterpenes were discerned: $y$-sitosterol $(4.206$ $\%), \psi$-taraxasterol (6.25\%), lupeol (5.036\%), lupenone $(4.65 \%)$, lupanol $(10.52 \%)$, and oleanolic acid $(7.55 \%)$.

\section{DISCUSSION}

The n-hexane fractions of $C$. polygonoides and C. adansonii were ascertained to have high 
Table 2: Components of the n-hexane extract of $C$. polygonoides from GC-MS

\begin{tabular}{|c|c|c|c|}
\hline Constituent & Retention time (min) & Molecular formula & Relative area (\%) \\
\hline 3-Hexen-1-ol & 10.22 & $\mathrm{C}_{6} \mathrm{H}_{12} \mathrm{O}$ & 1.5 \\
\hline 1-Hexanol & 10.66 & $\mathrm{C}_{6} \mathrm{H}_{14} \mathrm{O}$ & 0.85 \\
\hline Benzaldehyde & 11.58 & $\mathrm{C}_{7} \mathrm{H}_{6} \mathrm{O}$ & 0.56 \\
\hline 3-Pentanol, 2,4-dimethyl & 12.12 & $\mathrm{C}_{7} \mathrm{H}_{16} \mathrm{O}$ & 0.03 \\
\hline Hexanoic acid & 11.03 & $\mathrm{C}_{6} \mathrm{H}_{12} \mathrm{O}_{2}$ & 1.54 \\
\hline 2-Hexenal & 12.36 & $\mathrm{C}_{6} \mathrm{H}_{10} \mathrm{O}$ & 0.3 \\
\hline 2-Octen-1-ol & 14.45 & $\mathrm{C}_{8} \mathrm{H}_{16} \mathrm{O}$ & 0.77 \\
\hline Benzeneacetaldehyde & 15.28 & $\mathrm{C}_{8} \mathrm{H}_{8} \mathrm{O}$ & 1.2 \\
\hline 1-Octanol & 16.11 & $\mathrm{C}_{8} \mathrm{H}_{18} \mathrm{O}$ & 0.35 \\
\hline Octanal & 17.46 & $\mathrm{C}_{8} \mathrm{H}_{16} \mathrm{O}$ & 0.45 \\
\hline Nonanoic acid & 18.79 & $\mathrm{C}_{9} \mathrm{H}_{18} \mathrm{O}_{2}$ & 1.89 \\
\hline Decanal & 19.55 & $\mathrm{C}_{10} \mathrm{H}_{20} \mathrm{O}$ & 3.5 \\
\hline Decanoic acid & 21.1 & $\mathrm{C}_{10} \mathrm{H}_{20} \mathrm{O}_{2}$ & 2.5 \\
\hline Myristic acid & 22.2 & $\mathrm{C}_{14} \mathrm{H}_{28} \mathrm{O}_{2}$ & 0.633 \\
\hline Palmitoleic acid & 23.16 & $\mathrm{C}_{16} \mathrm{H}_{32} \mathrm{O}_{2}$ & 10.8 \\
\hline Palmitic acid & 24.05 & $\mathrm{C}_{16} \mathrm{H}_{32} \mathrm{O}_{2}$ & 12.5 \\
\hline Linoleic Acid & 24.16 & $\mathrm{C}_{18} \mathrm{H}_{32} \mathrm{O}_{2}$ & 6.2 \\
\hline Margaric acid & 24.25 & $\mathrm{C}_{17} \mathrm{H}_{34} \mathrm{O}_{2}$ & 15.5 \\
\hline a-linolenic acid & 24.37 & $\mathrm{C}_{18} \mathrm{H}_{32} \mathrm{O}_{2}$ & 9.3 \\
\hline Nonadecylic acid & 24.56 & $\mathrm{C}_{19} \mathrm{H}_{38} \mathrm{O}_{2}$ & 1.5 \\
\hline Heneicosylic acid & 24.85 & $\mathrm{C}_{21} \mathrm{H}_{42} \mathrm{O}_{2}$ & 4 \\
\hline Cycloartenol & 28.24 & $\mathrm{C}_{30} \mathrm{H}_{50} \mathrm{O}$ & 7.5 \\
\hline Cerotic acid & 29.14 & $\mathrm{C}_{26} \mathrm{H}_{52} \mathrm{O}_{2}$ & 1.2 \\
\hline Campesterol & 30.22 & $\mathrm{C}_{28} \mathrm{H}_{48} \mathrm{O}$ & 1.8 \\
\hline Stigmasterol & 30.65 & $\mathrm{C}_{29} \mathrm{H}_{48} \mathrm{O}$ & 6.99 \\
\hline Nonacosane & 32.57 & $\mathrm{C}_{29} \mathrm{H}_{60}$ & 3.7 \\
\hline Squalene & 32.89 & $\mathrm{C}_{30} \mathrm{H}_{50}$ & 6.3 \\
\hline Sitostenone & 33.09 & $\mathrm{C}_{29} \mathrm{H}_{48} \mathrm{O}$ & 5.3 \\
\hline$\beta$-Sitosterol & 34.55 & $\mathrm{C}_{29} \mathrm{H}_{50} \mathrm{O}$ & 12.8 \\
\hline$\beta$-Amyrin & 34.98 & $\mathrm{C}_{30} \mathrm{H}_{50} \mathrm{O}$ & 9.7 \\
\hline Dotriacontane & 35.12 & $\mathrm{C}_{32} \mathrm{H}_{66}$ & 20.65 \\
\hline Tritriacontane & 36.11 & $\mathrm{C}_{33} \mathrm{H}_{68}$ & 4.55 \\
\hline Untriacontane & 37.58 & $\mathrm{C}_{31} \mathrm{H}_{64}$ & 50.16 \\
\hline Tetratriacontane & 38.55 & $\mathrm{C}_{34} \mathrm{H}_{70}$ & 12.66 \\
\hline Pentatriacontane & 39.99 & $\mathrm{C}_{35} \mathrm{H}_{72}$ & 2.53 \\
\hline
\end{tabular}

Table 3: Components of the n-hexane extract of $C$. adansonii from GC-MS

\begin{tabular}{|c|c|c|c|}
\hline Constituent & $\begin{array}{l}\text { Retention } \\
\text { time (min) }\end{array}$ & $\begin{array}{c}\text { Molecular } \\
\text { formula }\end{array}$ & $\begin{array}{l}\text { Relative } \\
\text { area (\%) }\end{array}$ \\
\hline Pentadecane & 14.55 & $\mathrm{C}_{15} \mathrm{H}_{32}$ & 0.6 \\
\hline 2,6,10-Trimethyl Tetradecane & 15.757 & $\mathrm{C}_{17} \mathrm{H}_{36}$ & 0.785 \\
\hline 6,10,14-trimethyl-2-Pentadecanone & 18.479 & $\mathrm{C}_{18} \mathrm{H}_{36} \mathrm{O}$ & 0.66 \\
\hline Hexadecanoic Acid, Methyl Ester & 19.348 & $\mathrm{C}_{17} \mathrm{H}_{34} \mathrm{O}_{2}$ & 13.589 \\
\hline Hexadecanoic Acid, Ethyl Ester & 19.959 & $\mathrm{C}_{18} \mathrm{H}_{36} \mathrm{O}_{2}$ & 2.801 \\
\hline 9,12-Octadecadienoic Acid (Z,Z)-,methyl ester & 20.97 & $\mathrm{C}_{19} \mathrm{H}_{34} \mathrm{O}_{2}$ & 11.466 \\
\hline 9,12,15-Octadecatrienoic Acid (Z,Z,Z)-,methyl ester & 21.045 & $\mathrm{C}_{19} \mathrm{H}_{32} \mathrm{O}_{2}$ & 10.768 \\
\hline Phytol & 21.154 & $\mathrm{C}_{20} \mathrm{H}_{40} \mathrm{O}$ & 3.379 \\
\hline Octadecanoic Acid, Methyl Ester & 21.222 & $\mathrm{C}_{19} \mathrm{H}_{38} \mathrm{O}_{2}$ & 2.092 \\
\hline 9,12-Octadecadienoic Acid (Z,Z)-,Ethyl ester & 21.534 & $\mathrm{C}_{20} \mathrm{H}_{36} \mathrm{O}_{2}$ & 1.464 \\
\hline Octadecanoic Acid, Ethyl Ester & 21.785 & $\mathrm{C}_{20} \mathrm{H}_{40} \mathrm{O}_{2}$ & 0.688 \\
\hline Erucic Acid & 22.688 & $\mathrm{C}_{22} \mathrm{H}_{42} \mathrm{O}_{2}$ & 2.286 \\
\hline Docosanoic Acid, Methyl Ester & 24.534 & $\mathrm{C}_{23} \mathrm{H}_{46} \mathrm{O}_{2}$ & 0.66 \\
\hline 1,2-Benzene Dicarboxylic Acid, Mono(2-ethylhexyl)ester & 24.758 & $\mathrm{C}_{16} \mathrm{H}_{22} \mathrm{O}_{4}$ & 3.944 \\
\hline Heptacosane & 25.777 & $\mathrm{C}_{27} \mathrm{H}_{56}$ & 1.288 \\
\hline Nonacosane & 27.182 & $\mathrm{C}_{29} \mathrm{H}_{60}$ & 2.941 \\
\hline Tetratriacontane & 28.58 & $\mathrm{C}_{34} \mathrm{H}_{70}$ & 20.652 \\
\hline 17-Pentatriacontene & 29.205 & $\mathrm{C}_{35} \mathrm{H}_{70}$ & 0.549 \\
\hline Hexatriacontane & 29.836 & $\mathrm{C}_{36} \mathrm{H}_{74}$ & 8.216 \\
\hline y-Sitosterol & 30.366 & $\mathrm{C}_{29} \mathrm{H}_{50} \mathrm{O}$ & 4.206 \\
\hline Lupenone & 31.125 & $\mathrm{C}_{30} \mathrm{H}_{48} \mathrm{O}$ & 4.65 \\
\hline Lupeol & 31.106 & $\mathrm{C}_{30} \mathrm{H}_{50} \mathrm{O}$ & 5.036 \\
\hline$\Psi$-Taraxasterol & 33.32 & $\mathrm{C}_{30} \mathrm{H}_{50} \mathrm{O}$ & 6.25 \\
\hline Oleanolic acid & 29.65 & $\mathrm{C}_{30} \mathrm{H}_{48} \mathrm{O}_{3}$ & 7.55 \\
\hline Lupanol & 28.56 & $\mathrm{C}_{30} \mathrm{H}_{52} \mathrm{O}$ & 10.52 \\
\hline
\end{tabular}


urease-inhibitory activity, greater than the other fractions we collected. We used GC-MS to characterize the components in the fraction, and to provide some information as to the identify components with anti-urease activity. Fatty acids and lipids inhibit urease and the activity of $H$. pylori [26, 27]. Alkanes such as n-heptacosane havealso shown moderate urease inhibition [28], and several terpenoids (mono-, di-, and tri-) have anti-urease activity [29]. Of particular interest is the fact that oleanolic acid, which has displayed remarkable urease inhibition, has also been identified in the n-hexane fraction of $C$. adansonii [30-32]. We conclude that urease-inhibitory activity of these non-polar fractions can be attributed to the alkanes, fatty acids, sterols, triterpenes, and terpenoids present in them. To address the issue of rapid development of antimicrobial resistance, plant-based anti-urease agents with in vivo activity could be a direction for the development or discovery of novel antibacterial agents with enhanced efficacy and reduced antibiotic resistance [32-35]. Plantderived herbal formulations or secondary metabolites could also serve as cost-efficient antimicrobial agents with low toxicity and improved stability $[36,37]$.

\section{CONCLUSION}

The findings of this study reveal the presence of bioactive compounds that have been shown elsewhere to have anti-urease activity. Therefore, both plants contain compounds that are capable of urease inhibition. Few compounds with urease-inhibitory activity have been isolated from plants and established as clinically effective drugs. Thus, the phytochemicals identified in the present work may serve as candidates for further development as anti-urease agents for clinically applications.

\section{DECLARATIONS}

\section{Acknowledgement}

The authors are grateful to Department of Chemistry, F.C. College, Lahore for performing GC-MS of plant extracts.

\section{Conflict of interest}

No conflict of interest is associated with this study.

\section{Contribution of authors}

We declare that this work was done by the authors named in this article and all liabilities concerned with the claims relating to contents of this article will be borne by the authors. The study was conceived and designed by Prof. Dr. Saeed Ahmad, plants were collected by Irfan Pervaiz, and samples were dried and pulverized by Abdul Basit. Experimental work was conducted by Irfan Pervaiz and Adeel Arshad. Data handling and statistics application was done by Umair Khurshid. Manuscript was written by Irfan Pervaiz and Saeed Ahmad. All authors read and approved the manuscript for publication.

\section{Open Access}

This is an Open Access article that uses a funding model which does not charge readers or their institutions for access and distributed under the terms of the Creative Commons Attribution License (http://creativecommons.org/licenses/by/ 4.0) and the Budapest Open Access Initiative (http://www.budapestopenaccessinitiative.org/rea d), which permit unrestricted use, distribution, and reproduction in any medium, provided the original work is properly credited.

\section{REFERENCES}

1. Newman DJ, Cragg GM. Natural Products as Sources of New Drugs from 1981 to 2014. J Nat Prod 2016; 79(3): 629-661.

2. Hostettmann $K$, Marston A. The Search for New Drugs from Higher Plants. CHIMIA 2007; 61(6): 322-326.

3. Koehn FE, Carter GT. The evolving role of natural products in drug discovery. Nat Rev Drug Discov 2005; 4(3): 206-220.

4. Paterson I, Anderson EA. Chemistry. The renaissance of natural products as drug candidates. Science 2005; 310(5747): 451-453.

5. Krajewska B. Ureases I. Functional, catalytic and kinetic properties: A review. J Mol Catal B Enzym 2009; 59(1): 9-21.

6. Amirkia $V$, Heinrich $M$. Natural products and drug discovery: a survey of stakeholders in industry and academia. Front Pharmacol 2015; 6 (237): 1-8.

7. Andrews RK, Blakeley $R L$, Zerner B. Urea and urease. Adv Inorg Biochem 1984; 6: 245-283.

8. Mobley HL, Hausinger RP. Microbial ureases: significance, regulation, and molecular characterization. Microbiol Rev 1989; 53(1): 85-108.

9. Matongo F, Nwodo UU. In vitro assessment of Helicobacter pylori ureases inhibition by honey fractions. Arch Med Res 2014; 45(7): 540-546.

10. Shi DH, You ZL. Synthesis, characterization, and crystal structures of two Schiff base zinc(II) complexes with urease inhibitory activities. Russ J Coord Chem 2010; 36(7): 535-540.

11. Kobashi K. Urease activity of Helicobacter pylori: J Clin Pathol 1992; 45(4): 367-368.

Trop J Pharm Res, September 2019; 18(9): 1959 
12. Hassan ST, Berchova K, Majerova M, Pokorna M, Svajdlenka E. In vitro synergistic effect of Hibiscus sabdariffa aqueous extract in combination with standard antibiotics against Helicobacter pylori clinical isolates. Pharm Biol 2016; 54(9): 1736-1740.

13. Azizian H, Nabati F, Sharifi A, Siavoshi F, Mahdavi M, Amanlou M. Large-scale virtual screening for the identification of new Helicobacter pylori urease inhibitor scaffolds. J Mol Model 2012; 18(7): 2917-2927.

14. Modolo LV, de Souza AX, Horta LP, Araujo DP, de Fatima A. An overview on the potential of natural products as ureases inhibitors: A review. J Adv Res 2015; 6(1): 35-44.

15. Hassan ST, Zemlicka M. Plant-Derived Urease Inhibitors as Alternative Chemotherapeutic Agents. Arch Pharm 2016; 349(7): 507-522.

16. Trivedi PC. Ethnomedicinal Plants Of India: Aavishkar Publisher Distributors; 2007.

17. Khan AS. Medicinally Important Trees: Springer International Publishing; 2017.

18. Gitte TA, Kare MA, Deshmukh AM. Ethno- medicinal studies on barks of some medicinal plants in Marathwada (M. S.) India. Recent Res Sci Technol 2012; 4: 8-10.

19. Burkill HM, Dalziel JM, Hutchinson J, Royal Botanic Gardens K. The useful plants of West tropical Africa. Kew: Royal Botanic Gardens; 1985. 960 p.

20. Abdullahi A, Hamzah RU, Jigam AA, Yahya A, Kabiru AY, Muhammad H, Sakpe S, Adefolalu FS, Isah MC, Kolo MZ. Inhibitory activity of xanthine oxidase by fractions Crateva adansonii. J Acute Dis 2012; 1(2): 126-129.

21. Agbankpe AJ, Dougnon TV, Bankole SH, Houngbegnon O, Dah-nouvlessounon D, Baba-moussa L. In Vitro Antibacterial Effects of Crateva adansonii, Vernonia amygdalina and Sesamum radiatum Used for the Treatment of Infectious Diarrhoeas in Benin. J Infect Dis Ther 2016; 4(281): 1-7.

22. Tyagi BK. Advances in Vector Mosquito Control Technologies, with Particular Reference to Herbal Products. In: Vijay V, Gopalakrishnan R, editors. Herbal Insecticides, Repellents and Biomedicines: Effectiveness and Commercialization. New Delhi: Springer India; 2016. p. 1-9.

23. Pauw E, Eloff JN. Which tree orders in southern Africa have the highest antimicrobial activity and selectivity against bacterial and fungal pathogens of animals? BMC Complement Altern Med 2014; 14(317): 1472 6882.

24. Weatherburn MW. Phenol-hypochlorite reaction for determination of ammonia. Anal Chem 1967; 39(8): 971. 974.

25. Kubo J, Lee JR, Kubo I. Anti-Helicobacter pylori agents from the cashew apple. J Agric Food Chem 1999; 47(2): 533-537.
26. O'Connor CJ, Sun CQ, Roberton AM. Antibacterial actions of fatty acids and monoglycerides against Helicobacter pylori. FEMS Immunol Med Microbiol 2003; 36(1-2): 9-17.

27. Firdous S, Ansari NH, Fatima I, Malik A, Afza N, lqbal L, Lateef $M$. Ophiamides $A-B$, new potent urease inhibitory sphingolipids from Heliotropium ophioglossum. Arch Pharm Res 2012; 35(7): 1133-1137.

28. Bankeu Jean JK, Madjouka S, Feuya Guy RT, Fongang Yannick SF, Siddiqui S, Ali I, Mehreen L, Lenta Bruno N, Yousuf S, Noungoué Didérot $T$ et al. Pobeguinine: a monoterpene indole alkaloid and other bioactive constituents from the stem bark of Nauclea pobeguinii. Z Naturforsch C. 2018; 73(9-10): 335-344.

29. Khan SS, Khan A, Khan A, Wadood A, Farooq U, Ahmed $A$, Zahoor A, Ahmad VU, Sener B, Erdemoglu $N$. Urease inhibitory activity of ursane type sulfated saponins from the aerial parts of Zygophyllum fabago Linn. Phytomedicine 2014; 21(3): 379-382.

30. Golbabaei S, Bazl R, Golestanian S, Nabati F, Omrany $Z B$, Yousefi B, Hajiaghaee $R$, Rezazadeh S, Amanlou $M$. Urease inhibitory activities of $\beta$-boswellic acid derivatives. Daru. 2013; 21(1): 1-6.

31. Dawe A, Mbiantcha M, Fongang $Y$, Nana WY, Yakai $F$, Ateufack G, Shaiq MA, Lubna I, Lateef M, Ngadjui BT. Piptadenin, a Novel 3,4-Secooleanane Triterpene and Piptadenamide, a New Ceramide from the Stem Bark of Piptadeniastrum africanum (Hook.f.) Brenan. Chem Biodivers 2017; 14(2): 10.

32. Shin S-J, Park C-E, Baek N-I, Chung IS, Park C-H. Betulinic and oleanolic acids isolated from Forsythia suspensaVahl inhibit urease activity of Helicobacter pylori. Biotechnol Bioprocess Eng 2009; 14(2): 140-145.

33. Ziemniak W. Efficacy of Helicobacter pylori eradication taking into account its resistance to antibiotics. J Physiol Pharmacol 2006; 3: 123-141.

34. Cagdas U, Otag F, Tezcan S, Sezgin O, Aslan G, Emekdas G. [Detection of Helicobacter pylori and antimicrobial resistance in gastric biopsy specimens]. Mikrobiyol Bul 2012; 46(3): 398-409.

35. Yamamoto Y. Anti-Helicobacter pylori Activity of Natural Substances. In: Yamamoto Y, Friedman H, Hoffman PS, editors. Helicobacter pylori Infection and Immunity. Boston, MA: Springer US; 2002. p. 105-119.

36. Chandra $H$, Bishnoi $P$, Yadav A, Patni B, Mishra AP, Nautiyal AR. Antimicrobial Resistance and the Alternative Resources with Special Emphasis on PlantBased Antimicrobials-A Review. Plants 2017; 6(2).

37. Bonifacio $B V$, dos Santos Ramos $M A$, da Silva $P B$, Bauab TM. Antimicrobial activity of natural products against Helicobacter pylori: a review. Ann Clin Microbiol Antimicrob 2014; 13(1): 54. 